\title{
Ease of Doing Business: Gagasan Pembaruan Hukum Penyelesaian Sengketa Investasi di Indonesia
}

\author{
Teguh Tresna Puja Asmara ${ }^{1}$ \\ Isis Ikhwansyah ${ }^{2}$ \\ Anita Afriana ${ }^{3}$ \\ ${ }^{1}$ Email: teguh13001@mail.unpad.ac.id \\ ${ }^{2}$ Email: ikhwansyahisis@gmail.com \\ ${ }^{3}$ Email: anita.afriana@unpad.ac.id
}

Fakultas Hukum Universitas Padjadjaran Bandung, Indonesia

\begin{abstract}
Ease of Doing Business (EoDB) is a business ease indicator which issued by the World Bank. There are eleven indicators that become a benchmark in measuring the ease of doing business in a country. One of the indicators is related to the settlement of investment dispute or in this case is the enforcing contracts and resolving insolvency. Based on the Doing Business of 2019 report, currently the rating of ease of business in Indonesia occupies the position of 73 (seventy three). Indonesia's EoDB rating is still far from the target, which is ranked 40 (forty) in the world. This is due to dispute settlement in Indonesia still has a number of issues, both in terms of basic regulations, court proceedings and execution. Whereas in the business world (based on the EoDB indicator) a inexpensive, fast, and simple legal dispute settlement tool is needed. This research is a normative juridical legal research with the descriptive method of analysis, with results show that there are still no applying regulations of Law Number 25 of 2007 concerning on Investment which focused on discussing investment disputes, so that there is not clear legal certainty regarding to investment in Indonesia. In addition, there are also a number of issues related to bankruptcy cases, both of which are Law No. 37 of 2004 concerning Bankruptcy and Suspension of Obligation for Payment of Debts, some of which can lead to certain interests, length of bankruptcy court proceedings, and legal certainty after bankruptcy decisions. A breakthrough or update is needed that can support EoDB, one of which can be done in the field of investment dispute settlement especially related to the enforcing contracts and resolving insolvency by making applying regulations and revising related regulations.
\end{abstract}

Keywords: Investment; Dispute Settlement; Ease of Doing Business.

\begin{abstract}
ABSTRAK
Ease of Doing Business (EoDB) merupakan indikator yang berkaitan dengan kemudahan berbisnis yang dibuat oleh Bank Dunia. Terdapat sebelas indikator yang menjadi patokan dalam mengukur kemudahan berbisnis di suatu negara. Salah satu yang menjadi indikator yaitu terkait dengan penyelesaian sengketa investasi atau dalam hal ini penegakan kontrak dan penyelesaian perkara kepailitan. Berdasarkan laporan Doing Business 2019, peringkat kemudahan berbisnis di Indonesia berada pada posisi ke 73 (tujuh puluh tiga). Peringkat EoDB Indonesia tersebut masih jauh dari target yaitu masuk peringkat 40 (empat puluh) besar dunia. Hal ini disebabkan antara lain karena penyelesaian sengketa di Indonesia masih memiliki beberapa permasalahan baik itu dari segi dasar peraturan, proses persidangan dan pelaksanaan putusan. Sedangkan dalam dunia bisnis (berdasarkan indikator EoDB) dibutuhkan sarana penyelesaian sengketa yang murah, cepat, dan sederhana. Penelitian ini bersifat deskriptif analitis dengan menggunakan pendekatan yuridis normatif, dengan hasil menunjukan bahwa belum terdapat peraturan pelaksana dari Undang-undang Nomor 25 Tahun 2007 tentang Penanaman Modal yang fokus membahas sengketa investasi sehingga belum terciptanya kepastian hukum yang kuat dalam berivestasi di Indonesia. Selain itu, terdapat beberapa masalah terkait dengan penyelesaian perkara kepailitan, antara lain bersumber dari peraturannya yaitu Undangundang Nomor 37 Tahun 2004 tentang Kepailitan dan Penundaan Kewajiban Pembayaran Utang yang beberapa Pasalnya dapat mengarahkan kepada kepentingan tertentu, lamanya proses pengadilan
\end{abstract}


kepailitan, dan kepastian hukum pasca putusan kepailitan. Diperlukan suatu terobosan atau pembaruan yang dapat mendukung EoDB yaitu salah satunya dapat dilakukan pada bidang penyelesaian sengketa investasi khususnya terkait penegakan kontrak dan penyelesaian perkara kepailitan dengan cara membuat peraturan pelaksana dan merevisi peraturan terkait.

Kata Kunci: Investasi; Penyelesaian Sengketa; Kemudahan Berbisnis

\section{Pendahuluan}

Tujuan didirikannya negara Indonesia sebagaimana tercantum dalam pembukaan Undang-undang Dasar Negara Republik Indonesia Tahun 1945 (UUD 1945) salah satunya adalah menciptakan kesejahteraan umum. Dalam rangka mewujudkan kesejahteraan umum tersebut, negara yang diwakili perannya oleh Pemerintah diwajibkan melaksanakan pembangunan ekonomi nasional yang berkelanjutan dengan berlandaskan demokrasi ekonomi.

Indonesia dalam melaksanakan pembangunannya memerlukan modal dan investasi yang besar. Modal dan investasi yang dibutuhkan untuk pembangunan tersebut, tidak mungkin tercukupi hanya dari Pemerintah dan swasta nasional saja. Oleh karenanya, perlu didorong pula upaya semaksimal mungkin untuk menarik penanaman modal di Indonesia dari asing atau luar negeri.

Kegiatan penanaman modal di Indonesia telah diatur dalam Undang-undang Nomor 25 Tahun 2007 tentang Penanaman Modal (UUPM). Kehadiran UUPM diharapkan dapat memberikan perlindungan dan kepastian hukum bagi investor dalam negeri maupun asing sehingga bersedia menanamkan modalnya di Indonesia. Di dalam UUPM diatur salah satunya mengenai penyelesaian sengketa investasi, namun selain di dalam UUPM ini, ketentuan yang mengatur mengenai penyelesaian sengketa juga terdapat dalam perjanjian investasi bilateral yang dibuat oleh Indonesia dengan negara penanam modal. ${ }^{1}$

Globalisasi perdagangan adalah salah satu hal yang tidak dapat dihindari oleh suatu negara. Peningkatan aktivitas perdagangan lintas batas mengantarkan Indonesia pada ekonomi internasional yang terintegrasi. ${ }^{2}$ Indonesia sebagai negara yang aktif dalam kegiatan ekonomi global perlu menciptakan iklim penanaman modal yang kondusif, promotif, memberikan kepastian hukum, keadilan, dan efisien dengan tetap memperhatikan kepentingan ekonomi nasional.

Penanaman modal atau investasi dipengaruhi oleh banyak faktor dalam pelaksanaanya. Salah satu faktor yang dapat menarik minat pemilik modal adalah terkait

\footnotetext{
${ }^{1}$ Salim HS dan Budi Sutrisno. (2012). Hukum Investasi di Indonesia. (Cetakan Kedua). Jakarta: PT Raja Grafindo Persada, hlm. 1.

${ }^{2}$ Irma Ambarini Darmawan, Isis Ikhwansyah, dan Pupung Faisal. (2018). "Cross-Border Business Competition: Keabsahan dan Hambatan Penerapan Prinsip Ekstrateritorial dalam Penegakan Hukum Persaingan Usaha di Indonesia". Jurnal Bina Mulia Hukum 3 (1), 113-126.
} 
dengan kemudahan dalam melakukan investasi itu sendiri. Semakin mudah melakukan investasi, maka semakin mudah pula para investor melakukan ekspansi bisnisnya. Pengembangan skala usaha yang dilakukan oleh investor tersebut, dapat dilakukan dengan cara penanaman modal dalam negeri dan penanaman modal di luar negeri.

Investor dalam melakukan investasinya, menghadapi kemudahan dan hambatan yang berbeda-beda pada saat mengembangkan bisnisnya ke berbagai negara. Perbedaan kemudahan dalam melakukan investasi tersebut, mendorong munculnya indeks kemudahan berbisnis. Indeks Kemudahan Berbisnis atau Ease of Doing Business (EoDB) merupakan sebuah peringkat kemudahan berbisnis di suatu negara yang berdasarkan oleh beberapa indikator dan dibiayai Bank Dunia. ${ }^{3}$

EoDB telah menjadi acuan para investor dalam melakukan investasi di suatu negara. Semakin tinggi indeks EoDB suatu negara, maka semakin tinggi peluang negara tersebut dalam mendapatkan investor. EoDB dapat dijadikan parameter bagi suatu negara untuk menentukan indikator manakah yang harus dibenahi agar para investor mau melakukan investasi pada negara tersebut.

${ }^{3}$ Jamal Ibrahim Haidar. (2012). "The Impact of Business Regulatory Reforms on Economic Growth". Journals of The Japanese and International Economies 26 (3), 285-307.
Indikator terkait dengan kemudahan berbisnis dapat diukur sejak akan mulainya suatu bisnis, sampai dengan jika suatu bisnis berjalan tidak sesuai dengan rencana, dimana mengalami masalah atau kesulitan. Salah satu permasalahan atau kesulitan tersebut yang terjadi adalah masalah kesulitan keuangan yang mengakibatkan debitur tidak mampu membayar atau gagal bayar atas kewajiban atau utang-utangnya kepada kreditur atau yang lazim dikenal dengan istilah insolven. Gagal bayar dapat disebabkan karena debitor tidak mampu atau tidak mau membayar.

Berdasarkan laporan Doing Business 2019, peringkat kemudahan berbisnis di Indonesia berada pada posisi ke 73 (tujuh puluh tiga). Peringkat EoDB Indonesia tersebut masih jauh dari target yaitu masuk peringkat 40 (empat puluh) besar dunia. ${ }^{4}$ Ada 11 (sebelas) indikator untuk mengukur kemudahan berbisnis atau yang juga dikenal dengan istilah EoDB. Sebelas indikator tersebut diantaranya adalah memulai usaha (starting a business), perizinan terkait mendirikan bangunan (dealing with construction permit), penyambungan listrik (getting electricity, pendaftaran properti (registering property), akses perkreditan (getting credit), perlindungan terhadap investor minoritas (protecting minority

\footnotetext{
4 Dias Prasongko. Tempo. https://bisnis.tempo.co/ $\mathrm{read} / 1142191 /$ target-eodb-40-besar-darmin-nasu tiontahun-depan-harus-radikal/full\&view=ok (diakses 03 Mei 2019).
} 
investors), pembayaran pajak (paying taxes), perdagangan lintas negara (trading across border), pengaturan tenaga kerja (labor market regulation), penegakan kontrak (enforcing contracts), dan penyelesaian perkara kepailitan (resolving insolvency). ${ }^{5}$

Indikator yang menentukan kemudahan berbisnis salah satunya adalah terkait dengan penegakan kontrak dan penanganan perkara kepailitan. Dalam hal penegakan kontrak di Indonesia belum terdapat peraturan pelaksana terkait dengan penyelesaian investasi dari UUPM sehingga menimbulkan kepastian hukum yang lemah untuk investor.

Khusus mengenai penanganan perkara kepailitan, ada dua aspek utama yang diukur, yaitu aspek kerangka hukum dan efisiensi penanganan kepailitan. Pada aspek kerangka hukum, penanganan kepailitan dinilai dari sejauh mana kerangka hukum kepailitan memberikan kepastian dan perlindungan hukum serta hak-hak debitur dan kreditur pada proses penanganan kepailitan sampai selesainya proses. Sementara itu, pada aspek kedua, yaitu efisiensi penanganan kepailitan, penanganan kepailitan diukur dari biaya dan waktu serta hasil dari proses kepailitan serta pasca putusan kepailitan.

Penegakan kontrak dan penanganan perkara kepailitan di Indonesia mengalami beberapa permasalahan baik itu dari segi dasar peraturan, proses persidangan dan

\footnotetext{
${ }^{5}$ World Bank Group. (2019). "Doing Business 2019". A World Bank GroupFlagship Report, hal. 2.
}

pelaksanaan putusan. Permasalahan penyelesaian sengketa investasi tersebut dapat dilihat dari adanya peraturan perundang-undangan yang salah satu Pasalnya dapat mengarah kepada kepentingan tertentu, lama dan mahalnya proses penyelesaian sengketa, dan tidak adanya kepastian hukum pasca putusan sengketa.

Guna mengatasi permasalah penegakan kontrak dan penanganan perkara kepailitan di Indonesia dalam rangka mendukung EoDB diperlukan pembaruan dan penyempurnaan terkait peraturan penyelesaian sengketa investasi. Hal tersebut juga sebagai upaya penyempurnaan pembangunan hukum di bidang investasi yang merupakan program hukum secara nasional. ${ }^{6}$ Langkah konkrit yang dapat dilakukan adalah dengan membuat peraturan pelaksana dari UUPM yang khusus mengenai penyelesaian sengketa dan merevisi Undang-undang Nomor 37 Tahun 2004 tentang Kepailitan dan Penundaan Kewajiban Pembayaran Utang (UU Kepailitan dan PKPU).

Berbeda dengan artikel-artikel lainnya, artikel ini fokus membahas penelitian mengenai indikator EoDB dalam hal penegakan kontrak dan penanganan perkara kepailitan yang merupakan kompentensi Penulis. Penelitian ini penting agar lembaga

6 Suradiyanto. (2015). "Pembangunan Hukum Investasi dalam Peningkatan Penanaman Modal di Indonesia”. DIH Jurnal Ilmu Hukum, 11 (21), 25-32. 
penyelesaian sengketa investasi dapat lebih efektif dan memberikan jaminan kepastian hukum yang kuat kepada para investor sehingga dapat mendukung EoDB di Indonesia.

Berdasarkan uraian di atas, maka Penulis tertarik untuk mengangkat beberapa permasalahan di antaranya: Pertama, bagaimana telaah yuridis pelaksanaan penanaman modal di Indonesia. Kedua, bagaimana metode dan masalah-masalah penyelesaian sengketa investasi di Indonesia. Ketiga, bagaimana gagasan pembaruan penyelesaian sengketa investasi dalam mendukung EoDB di Indonesia.

\section{Metode Penelitian}

Metode penelitian yang digunakan dalam artikel ini menggunkan metode pendekatan yuridis normatif yaitu metode penelitian hukum yang mengutamakan cara meneliti bahan pustaka atau yang disebut bahan data sekunder berupa hukum positif dalam hal ini yang mengatur tentang penanaman modal, kemudahan berbisnis, penyelesaian sengketa investasi dan contoh putusan sengketa investasi. Metode pendekatan yuridis normatif yang digunakan dalam penelitian ini mencakup penelitian terhadap asas-asas hukum, sistematika hukum, dan sinkronisasi hukum. Penelitian ini bersifat deskriptif analitis, yang melukiskan fakta-fakta dari data yang diperoleh berdasarkan kenyataan dalam hal ini kegiatan terkait penanaman modal, kemudahan berbisnis, dan penyelesaian sengketa investasi di Indonesia. Fakta tersebut kemudian dianalisa dengan hukum yang berlaku dan ditarik kesimpulan.

\section{Analisis dan Pembahasan}

\section{A. Telaah Yuridis Pelaksanaan}

\section{Penanaman Modal di Indonesia}

Investasi merupakan salah satu sarana guna menyelenggarakan pemba-ngunan nasional di suatu negara. Dalam rangka menyelenggarakan pembangunan nasional di bidang ekonomi, negara yang sedang melaksanakan pembangunan biasanya menghadapi beberapa masalah diantaranya yaitu kekurangan modal, kemampuan dalam hal teknologi, ilmu pengetahuan, pengalaman, dan keteram-pilan. Guna mengatasi masalah ekonomi dalam kebutuhan modal, salah satu sumber pembiayaan dan sumber daya yang dapat dimanfaatkan untuk pembangunan nasional tersebut adalah penanaman modal yang terselenggara melalui berbagai bentuk penanaman modal baik domestik maupun asing.

Pelaksanaan penanaman modal atau investasi di Indonesia diatur dalam UUPM. Penanaman modal berdasarkan UUPM tersebut merupakan segala bentuk kegiatan menanam modal, baik oleh penanam modal dalam negeri maupun penanam modal asing 
untuk melakukan usaha di wilayah negara Republik Indonesia.

Tujuan diselenggarakannya penanaman modal di Indonesia sebagaimana diatur dalam Pasal 3 Ayat (2) UUPM yaitu untuk meningkatkan pertumbuhan ekonomi nasional, menciptakan lapangan kerja, meningkatkan pembangunan ekonomi berkelanjutan, meningkatkan kemampuan daya saing dunia usaha nasional, meningkatkan kapasitas dan kemampuan teknologi nasional, mendorong pengembangan ekonomi kerakyatan, dan mengolah ekonomi potensial menjadi kekuatan ekonomi riil dengan menggunakan dana yang berasal, baik dari dalam negeri maupun dari luar negeri.

Pertumbuhan ekonomi suatu negara merupakan dapat dijadikan sebuah indikator atas keberhasilan pembangunan ekonomi. Pertumbuhan ekonomi yang berkelanjutan adalah pertumbuhan yang ditopang oleh investasi. ${ }^{7}$ Kebijakan pemerintah khususnya di bidang penanaman modal yang ditujukan untuk meningkatkan pertumbuhan ekonomi nasional adalah ditetapkan dan dikembangkannya kawasan ekonomi khusus yang dimaksudkan untuk pengembangan ekonomi di wilayah tertentu yang bersifat strategis bagi pengembangan ekonomi

\footnotetext{
7 Ratnasari Fajariya Abidin. (2017). "Harmonisasi Peraturan Penanaman Modal Asing dalam Bidang Pertambangan Mineral Dan Batubara Berdasarkan Prinsip Keadilan”. Jurnal Az Zarqa, 9 (2), 315-364.
}

nasional dan untuk menjaga keseimbangan kemajuan suatu daerah.

Dalam melaksanakan penanaman modal, selain memperhatikan kepentingan pengusaha atau investor, harus juga mementingkan kepentingan bangsa dan negara Indonesia. Perhatian terhadap kepentingan pembangunan tersebut diimplementasikan salah satunya melalui peraturan yang mengharuskan investor dalam melakukan penanaman modal dalam memenuhi kebutuhan tenaga kerja mengutamakan tenaga kerja warga negara Indonesia dan diwajibkan meningkatkan kompetensi tenaga kerja warga negara Indonesia melalui pelatihan kerja serta mewajibkan bagi perusahaan yang mempekerjakan tenaga kerja asing untuk menyelenggarakan pelatihan dan melaku-kan alih teknologi kepada tenaga kerja warga negara Indonesia.

Guna mendukung pembangunan ekonomi yang berkelanjutan investor yang ingin menanamkan modalnya di Indonesia haruslah melaksanakan tanggung jawab sosial dan lingkungan perusahaan. Tanggung jawab sosial dan lingkungan tersebut dapat dalam hal memelihara dan melestarikan lingkungan maupun memberdayakan masyarakat.

Peningkatan kapasitas dan kemampuan teknologi nasional dapat diwujudkan secara konkret dalam rumusan kebijakan di bidang penanaman modal, khususnya mengenai 
kewajiban perusahaan penanaman modal yang mempekerjakan tenaga kerja asing untuk menyelenggarakan pelatihan dan melakukan alih teknologi kepada tenaga kerja warga negara Indonesia sesuai dnegan ketentuan peraturan perundang-undangan.

Pengembangan ekonomi kerakyatan dalam penanaman modal dapat tercermin pada kebijakan yang memberikan perlindungan terhadap pelaku usaha mikro, kecil, dan menengah, dan koperasi, dimana pemerintah diwajibkan menetapkan bidang usaha yang dicadangkan untuk usaha mikro, kecil, dan menengah, dan koperasi serta bidang usaha yang terbuka untuk usaha besar dengan syarat harus bekerja sama dengan mikro, kecil, dan menengah, dan koperasi. Disamping itu, pemerintah diwajibkan pula untuk melakukan pembinaan dan pengembangan usaha mikro, kecil, dan menengah, dan koperasi melalui program kemitraan, peningkatan daya saing, pemberian dorongan inovasi dan perluasan pasar, serta penyebaran informasi yang seluas-luasnya.

Penanaman modal di Indonesia sebagaimana diatur dalam UUPM harus diselenggarakan berdasarkan beberapa asas yaitu kepastian hukum, keterbukaan, akuntabilitas, perlakuan yang sama dan tidak membedakan asal negara, kebersamaan, efisiensi berkeadilan, berkelanjutan, berwawasan lingkungan, kemandirian, dan keseimbangan kemajuan dan kesatuan ekonomi nasional.

Investasi disuatu negara memerlukan lembaga pengoordinasi yang bertugas untuk memastikan investasi atau penanaman modal berjalan baik. Berdasarkan UUPM, badan yang mengoordinasi kegiatan investasi di Indonesia adalah Badan Koordinasi Penanaman Modal (BKPM). Badan tersebut dibuat dengan adanya kewajiban dari Pemerintah untuk mengoordinasi kebijakan penanaman modal, baik koordinasi antarinstansi Pemerintah, antarinstansi Pemerintah dengan Bank Indonesia, antarinstansi Pemerintah dengan pemerintah daerah, maupun antarpemerintah daerah. BKPM dipimpin oleh seorang kepala yang diangkat oleh Presiden serta bertanggung jawab langsung kepada Presiden.

Berdasarkan UUPM tepatnya dalam Pasal 28 Ayat (1) disebutkan bahwa BKPM memiliki beberapa tugas dan fungsi antara lain: Pertama, melaksanakan tugas dan koordinasi pelaksanaan kebijakan di bidang penanaman modal. Kedua, mengkaji dan mengusulkan kebijakan pelayanan penanaman modal. Ketiga, menetapkan norma, standar, dan prosedur pelaksanaan kegiatan dan pelayanan penanaman modal. Keempat, mengembangkan peluang dan potensi penanaman modal di daerah dengan memberdayakan badan usaha. Kelima, membuat peta penanaman modal Indonesia. Ketujuh, mempromosikan penanaman modal. 
Kedelapan, mengembangkan sektor usaha penanaman modal melalui pembinaan penanaman modal, antara lain meningkatkan kemitraan, meningkatkan daya saing, menciptakan persaingan usaha yang sehat, dan menyebarkan informasi yang seluasluasnya dalam lingkup penyelenggaraan penanaman modal. Kesembilan, membantu penyelesaian berbagai hambatan dan konsultasi permasalahan yang dihadapi penanam modal dalam menjalankan kegiatan penanaman modal. Kesepuluh, mengoordinasi penanam modal dalam negeri yang menjalankan kegiatan penanaman modalnya di luar wilayah Indonesia. Dan kesebelas, mengoordinasi dan melaksanakan pelayanan terpadu satu pintu.

\section{B. Metode dan Masalah-masalah} Penyelesaian Sengketa Investasi di

\section{Indonesia}

Penyelesaian sengketa merupakan pernyataan publik mengenai tuntutan yang tidak selaras (inconsistent claim) terhadap sesuatu yang bernilai. ${ }^{8}$ Penyelesaian sengketa bisnis di Indonesia dapat dilakukan melalui dua macam cara, yaitu melalui Pengadilan atau sering disebut sebagai litigasi dan non Pengadilan atau sering disebut sebagai non litigasi. Litigasi merupakan proses

${ }^{8}$ Huala Adolf. (2006). Hukum Perdagangan Internasional. Jakarta: Raja Grafindo Persada, hlm. 65. penyelesaian sengketa di Pengadilan, dimana pihak yang bersengketa saling berhadapan satu sama lain untuk mempertahankan hakhaknya di muka pengadilan. Hasil akhir dari suatu penyelesaian sengketa melalui litigasi adalah putusan yang menyatakan win-lose solution atau dengan kata lain ada yang dikalahkan dan ada yang dimenangkan.

Prosedur dalam jalur litigasi ini sifatnya lebih formal dan sangat teknis. Hal tersebut dikarenakan hukum acara yang wajib dipenuhi oleh Pengadilan dalam beracara. Dengan sifat yang formal dan sangat teknis tersebut, menyebabkan penyelesaian sengketa di jalur litigasi kurang diminati terutama dalam masalah penyelesaian sengketa bisnis. Kegiatan bisnis yang dinamis dan memiliki karakter khusus menyebabkan para pihak di dalamnya memerlukan penyelesaian sengketa yang sederhana, cepat, dan biaya ringan, yang mana dalam hal ini dapat diakomodir melalui cara penyelesaian sengketa alternatif yang sering disebut Alternative Dispute Resolution (ADR). ${ }^{9}$

Penyelesaian sengketa melalui nonlitigasi sering juga disebut sebagai Alternatif Penyelesaian Sengketa (APS). APS diatur dalam Undang-undang Nomor 30 Tahun 1999 Tentang Arbitrase dan Alternatif Penyelesaian Sengketa (UU Arbitrase dan

\footnotetext{
${ }^{9}$ Anita Afriana. (2015). "Penerapan Acara Singkat dan Acara Cepat dalam Penyelesaian Sengketa Perdata di Pengadilan: Suatu Tinjauan Politik Hukum Acara Perdata”. Jurnal Hukum Acara Perdata, 1 (1), 31-44.
} 
APS). Berdasarkan Pasal 1 Angka (10) UU Arbitrase dan APS dijelaskan bahwa APS merupakan lembaga penyelesaian sengketa atau beda pendapat melalui prosedur yang disepakati para pihak, yakni penyelesaian sengketa di luar Pengadilan dengan cara konsultasi, mediasi, konsiliasi, atau penilaian ahli.

Penjelasan terkait masing-masing cara penyelesaian di luar Pengadilan tersebut adalah sebagai berikut: ${ }^{10}$ Pertama, konsultasi merupakan suatu tindakan yang bersifat "personal" antara suatu pihak tertentu (klien) dengan pihak lain yang merupakan pihak konsultan, dimana pihak konsultan memberikan pendapatnya kepada klien sesuai dengan keperluan dan kebutuhan kliennya. Kedua, negosiasi merupakan penyelesaian sengketa para pihak tanpa melalui proses Pengadilan dengan tujuan mencapai kesepakatan bersama atas dasar kerja sama yang lebih harmonis dan kreatif. Ketiga, mediasi merupakan cara penyelesaian sengketa melalui proses perundingan untuk memperoleh kesepakatan para pihak dengan dibantu oleh mediator, dalam perkembangannya mediasi juga ada di dalam Pengadilan. Keempat, konsiliasi merupakan cara penyelesaian sengketa dengan adanya penengah yang akan bertindak menjadi konsiliator dengan kesepakatan para pihak

\footnotetext{
${ }^{10}$ Frans Hendra Winarta. (2011). Hukum Penyelesaian Sengketa-Arbitrase Nasional Indonesia \& Internasional. Jakarta: Sinar Grafika, hlm. 7-8.
}

dengan mengusahakan solusi yang dapat diterima. Kelima, penilaian ahli yaitu merupakan pendapat para ahli untuk suatu hal yang bersifat teknis dan sesuai dengan bidang keahliannya.

Dalam bidang investasi, penyelesaiannya sengketa di Indonesia telah diatur dalam UUPM. Pasal 32 UUPM menjelaskan bahwa dalam hal terjadi sengketa di bidang penanaman modal antara Pemerintah dengan penanam modal atau para pihak terlebih dahulu harus menyelesaikan sengketa tersebut melalui musyawarah dan mufakat. Apabila tidak tercapai musyawarah mufakat, penyelesaian sengketa tersebut dapat dilakukan melalui arbitrase atau APS atau pengadilan sesuai dengan ketentuan peraturan perundang-undangan. Sengketa yang timbul dalam penanaman modal merupakan bagian dari sengketa bisnis yang sesungguhnya secara prinsip harus diselesaikan secara cepat.

UUPM telah mengatur setidaknya tiga cara penyelesaian sengketa penanaman modal yakni penyelesaian berdasarkan musyawarah mufakat, melalui arbitrase atau alternatif penyelesaian sengketa serta melalui pengadilan. ${ }^{11}$ Pasal 32 UUPM pada intinya mengharuskan penyelesaian sengketa investasi antara pemerintah dan penanam modal asing secara musyawarah dan

\footnotetext{
11 Helmi Kasim. (2018). “Arbitrase sebagai Mekanisme Penyelesaian Sengketa Penanaman Modal”. Jurnal RechtsVinding, 7 (1), 79-96.
} 
mufakat. Jika penyelesaian sengketa secara musyawarah dan mufakat tidak tercapai, maka penyelesaian sengketa investasi antara pemerintah dan penanam modal dapat diselesaikan melalui arbitrase atau APS.

Apabila terjadi sengketa di bidang penanaman modal antara Pemerintah dengan penanam modal dalam negeri, para pihak dapat menyelesaikan sengketa tersebut melalui arbitrase berdasarkan kesepakatan para pihak, dan jika penyelesaian sengketa melalui arbitrase tidak disepakati, penyelesaian sengketa tersebut akan dilakukan di Pengadilan. Selain itu, sengketa di bidang penanaman modal antara Pemerintah dengan penanam modal asing, para pihak akan menyelesaikan sengketa tersebut melalui arbitrase internasional yang harus disepakati oleh para pihak.

Arbitrase berdasarkan UU Arbitrase dan APS merupakan cara penyelesaian suatu sengketa perdata di luar peradilan umum yang didasarkan pada perjanjian arbitrase yang dibuat secara tertulis oleh para pihak yang bersengketa. Sengketa yang memilih jalur arbitrase menyebabkan Pengadilan tidak berwenang dalam mengadili sengketa yang sama. Pengadilan wajib menolak serta tidak akan campur tangan di dalam suatu penyelesaian sengketa yang telah ditetapkan melalui arbitase. Pelesaian sengketa melalui arbitrase diwajibkan untuk dibuatkan atau dicantumkan dalam perjanjian para pihak.
Penyelesaian sengketa investasi dalam pengaturannya tidak hanya diatur dengan hukum nasional, melainkan juga dengan hukum negara investor, dan yang tidak kalah pentingnya ialah pengaturan menurut hukum internasional, baik yang bersifat privat maupun bersifat publik. Selain itu terdapat arbitrase-arbitrase internasional yang salah satunya bergerak dalam penyelesaian sengketa penanaman modal yaitu International Centre for Settlement of Investment Disputes (ICSID).

Penyelesaian sengketa investasi melalui Pengadilan dirasakan kurang adil oleh investor dikarenakan putusannya bersifat win-lose solution. Selain itu, terdapat masalah-masalah seperti lama dan kakunya proses beracara di Pengadilan menjadikan para investor cenderung menganggap cara penyelesaian sengketa melalui Pengadilan tidak efektif dan tidak efisien. Oleh karenanya para pelaku bisnis cenderung memilih penyelesaian sengketa melalui arbitrase atau APS, yang mana cara penyelesaian sengketa tersebut dapat memberikan penyelesaian sengketa yang cepat, sederhana, dan berbiaya ringan.

Selain masalah mengenai dasar peraturan, pemilihan metode penyelesaian sengketa, waktu, biaya, dan ketidakpastian hukum pasca putusan dalam hal penyelesaian sengketa investasi, terdapat juga masalah mengenai ketidakpastian hukum terhadap investor asing dalam kegiatan penanaman 
modal yang dapat dilihat dalam kasus PT Socfin Indonesia (Socfindo).

Berdasarkan Putusan Pengadilan Tata Usaha Negara dengan No. 82/G/2009/PTUNMdn kemudian dikuatkan dengan Putusan Pengadilan Tinggi Tata Usaha Negara dengan No. 39/BDG/2010/PT.TUN-Mdn dan Putusan Mahkamah Agung RI dengan No. $382 \mathrm{~K} / \mathrm{TUN} / 2010$, menyatakan bahwa sertifikat Hak Guna Usaha (HGU) milik PT Socfin Indonesia (Socfindo) yang digugat oleh para petani yang mengaku sebagai pemilik tanah yang berasal dari peninggalan orang tua mereka, dibatalkan dan dicabut.

Kasus yang berdasarkan putusan tersebut dapat menjadi sebab terhambatnya investasi dan menurunkan indeks kemudahan berbisnis Indonesia khususnya dalam bidang penyelesaian sengketa investasi. Hal ini tiada lain dikarenakan tidak adanya kepastian hukum bagi investor dan tiak didahulukannya penyelesaian sengketa investasi yang win-win solution. Dengan dibuatnya peraturan pelaksana dari UUPM yang fokus membahas sengketa investasi diharapkan penyelesaian sengketa dalam hal investas semaksimal mungkin dapat diselesaikan dengan cara yang sama-sama menguntungkan para pihak terutama pihak investor.

C. Gagasan Pembaruan Penyelesaian Sengketa Investasi dalam Mendukung EoDB di Indonesia
1. Kemudahan

Berberbisnis

\section{Berdasarkan Ketentuan Bank Dunia}

Kemudahan berinvestasi di suatu negara dewasa ini dapat diukur oleh beberapa indikator yang dikeluarkan oleh bank dunia dengan proyeknya yang bernama The Doing Business. Proyek The Doing Business merupakan suatu proyek Global International Finance Corporation oleh World Bank Group yang menyediakan penilaian dalam regulasi bisnis secara objektif dan penerapannya (regulasi) terhadap 190 negara serta kota-kota terpilih di tingkat provinsi dan kabupaten atau kota dalam bentuk sebuah laporan. Proyek yang telah ada sejak tahun 2002 ini melakukan penelitian kepada perusahaan dari yang berskala kecil hingga perusahaanperusahaan besar di suatu negara dan mengukur suatu aturan yang diterapkan kepada mereka (perusahaan) dalam kegiatan bisnis yang mereka lakukan. Doing Business ini menyediakan berbagai laporan atas regulasiregulasi tentang bisnis dalam penerapannya oleh perusahaan. Laporan-laporan ini berupa data tentang kemudahan berbisnis, dan rokemendasi-rekomendasi untuk meningkatkan pelaksanaan kemudahan

Pada intinya EoDB merupakan peringkat atau indeks kemudahan berbisnis yang dibuat oleh Bank Dunia. Indeks ini merupakan peringkat ekonomi dengan skala 1-190 (tergantung kepada jumlah negara yang menjadi objek survei oleh Bank Dunia) 
tentang kemudahan berbisnis dalam suatu negara yang diukur berdasarkan penerapan regulasi bisnis kepada perusahaan dan atau pelaku usaha serta pengalaman mereka dalam kegiatan berusaha dan berbisnis. Data Doing Business kerap digunakan untuk menilai kondisi perekonomian dan peraturan dalam melakukan penanaman modal asing ke suatu negara atau foreign direct investmen (FDI). ${ }^{12}$

Semakin tinggi peringkat suatu negara menunjukkan bahwa negara tersebut mempunyai tingkat kemudahan berbisnis semakin baik. Negara-negara dengan tingkat kemudahan bisnis yang baik tentu dapat dibilang lebih bersahabat dengan investor. Semakin mudah investor melakukan penanaman modal, semakin besar juga kesempatan negara tersebut untuk mengembangkan sektor-sektor potensial seperti sektor ekonomi, pariwisata dan lainlain.

Ada 11 (sebelas) indikator untuk mengukur kemudahan berbisnis atau yang juga dikenal dengan istilah EoDB. Sebelas indikator tersebut diantaranya adalah memulai usaha (starting a business), perizinan terkait mendirikan bangunan (dealing with construction permit), penyambungan listrik (getting electricity, pendaftaran properti (registering property), akses perkreditan (getting credit),

\footnotetext{
${ }^{12}$ Adrian Corcoran dan Robert Gillanders. (2012). "Foreign Direct Investment and The Ease of Doing Business". Review of World Economics 151 (1), 103126.
}

perlindungan terhadap investor minoritas (protecting minority investors), pembayaran pajak (paying taxes), perdagangan lintas negara (trading across border), pengaturan tenaga kerja (labor market regulation), penegakan kontrak (enforcing contracts), dan penyelesaian perkara kepailitan (resolving insolvency).

Berikut uraian terkait dengan masingmasing indikator EoDB: Pertama, Memulai Usaha (Starting a Business). Tahapan Memulai Usaha dimaksudkan sebagai fase awal berusaha yang berisi presedur, lama waktu dan jumlah biaya yang harus dipenuhi pengusaha saat mendirikan badan usaha dan menjalankan operasional bisnis secara resmi. Dan segala bentuk proses kegiatan pengurusan berbagai perizinan yang perlu dilakukan untuk memulai usaha Kecil dan Menengah.Dari sisi indikator memulai usaha terdapat empat aspek perbaikan yang dapat dilakukan, yang diantaranya adalah persyaratan modal minimal, penyederhanaan prosedur, waktu penyelesaian, dan biaya yang dikeluarkan.

Kedua, Perizinan Mendirikan Bangunan (Dealing with Construction Permits). Bangunan usaha dalam pembuatan atau pendiriannya merupakan indikator terpisah yang memiliki prosedur tersendiri. Indikator tersebut menjadi faktor penting pada saatsaat awal usaha, terutama bagi perusahaan yang pada fase operasional memiliki kegiatan utama perdagangan, 
penyimpanan barang dan distribusi hasil produk. Dengan melihat siklus usaha tersebut maka kemudahan dalam mengurus dan mendapatkan izin-izin pendirian bangunan (gudang) menjadi hal penting yang harus disederhanakan.

Ketiga, Penyambungan Listrik (Getting Electricity). Listrik merupakan salah satu kebutuhan yang sangat penting dalam melakukan berusaha terutama terkait tempat yang digunakan sebagai sarana berusaha tersebut. Mendapatkan sambungan listrik adalah salah satu indikator penilaian Bank Dunia dalam EoDB. Asumsi bangunan yang digunakan oleh Bank Dunia dalam mengukur indikator penyambungan listrik hanya untuk sambungan listrik bangunan gudang berukuran minimal $929 \mathrm{~m}^{2}$ (luas tanah minimal 1.300,6 $\mathrm{m}^{2}$ ), bangunan baru dan pertama kali tersambung listrik, listrik yang tersambung dengan daya 140 KVA, dan pemakaian minimal listrik sebulannya minimal 0,07 GWH.

Keempat, Pendaftaran Properti (Registering Property). Properti dalam hal ini salah satunya berupa tanah yang juga menjadi objek penting dalam penilaian indikator EoDB. Tanah tanpa kepastian status kepemilikan atau berbelit dalam pengurusan peralihan hak, jelas menghambat nilai manfaat penggunaanya. Indikator ini berisi rangkaian proses bisnis yang wajib diurus penjual dan pembeli agar properti dapat beralih hak secara sah. Sebagaimana kedua indikator lainnya, indikator Registering Property berisi data-data utama yang sama (prosedur, waktu, biaya) dengan perbedaan terletak pada data khusus perihal kualitas pelayanan administrasi. Sebagian interaksi berlang-sung dengan instansi vertikal Pusat di daerah (BPN), sebagian lainnya dengan instansi Pemda dan para pihak ketiga seperti Notaris/PPAT. Rangkaian prosedur, waktu dan biaya dilakukan bersamaan atau terpisah menurut klasifikasi tahapan: pra-registrasi, registrasi dan postregistrasi.

Kelima, Akses Perkreditan (Getting Credits). Akses perkreditan merupakan salah satu hal penting dalam berusaha yang perlu diperhatikan terutama bagi para investor yang masih membutuhkan tambahan dana. Dalam hal ini menyoroti terkait permasalahan hak legal peminjam dan pemberi pinjaman berkaitan dengan transaksi yang dijamin dan detail informasi dalam pemberian kredit. Indikator akses perkreditan termasuk juga yang menjadi objek penilaian dalam rangkaian kemudahan berbisnis.

Keenam, Perlindungan Pemegang Saham Minoritas (Protecting Minority). Kepastian hukum adalah salah satu faktor yang dapat melindungi para investor, baik itu investor yang memiliki saham mayoritas maupun saham minoritas. Indikator perlindungan pemegang saham minoritas adalah salah satu dari Indikator penilaian yang ada dalam survey EoDB yang 
dilakukan oleh Bank Dunia. Indikator ini berfokus pada aturan/praktik perlindungan terhadap pemegang saham minoritas di suatu negara.

Ketujuh, Pembayaran Pajak (Paying Taxes). Dalam melakukan usaha tentu tidak terlepas dengan wajib membayar pajak yang merupakan kontribusi wajib kepada negara yang terutang oleh orang pribadi atau badan yang bersifat memaksa berdasarkan UndangUndang, dengan tidak mendapatkan imbalan secara langsung dan digunakan untuk keperluan negara bagi sebesar-besarnya kemakmu-ran rakyat. Indikator pembayaran pajak mencerminkan jumlah total pajak dan iuran yang dibayarkan, metode pembayaran, frekuensi pembayaran, dan jumlah lembaga yang terlibat untuk studi kasus selama tahun kedua operasi. Ini termasuk pajak yang dipotong oleh perusahaan, pajak pertambahan nilai (PPN) dan pajak tenaga kerja karyawan (PPh 21). Pajak ini dipungut/dipotong oleh perusahaan dari konsumen atau karyawan. Meskipun mereka tidak mempengaruhi laporan laba rugi perusahaan, mereka menambah beban administrasi sesuai dengan sistem pajak dan termasuk dalam ukuran pembayaran pajak.

Kedelapan, Perdagangan Lintas Negara (Trading Across Borders). Perdagangan di masa modern dewasa ini tidak dapat lepas dari perdagangan golobal atau antar negara. Perdagangan lintas negara tersebut juga termasuk salah satu yang dinilai oleh Bank
Dunia dalam melakukan survey kemudahan berbisnis yakni berkenaan dengan masalah impor dan ekspor dalam kegiatan perdagangan oleh pelaku usaha/perusahaan di Indonesia. Indikator ini menilai sejauh mana kemudahan ekspor dan impor barang dilakukan.

Kesembilan, Pengaturan Tenaga Kerja (Labor Market Regulation). Ketentuan mengenai tenaga kerja di Indonesia diatur dalam Undang-undang Nomor 13 tahun 2003 tentang Ketenagakerjaan Ketenagakerjaan). Ketentuan mengenai penggunaan tenaga kerja asing diatur secara khusus dalam UU Ketenagakerjaan tepatnya pada Bab VIII Pasal 42 sampai dengan Pasal 49.

Kesepuluh, Penegakan Kontrak (Enforcing Contracts). Penegakan kontrak adalah indikator yang mengukur biaya dan waktu yang diperlukan dalam menyelesaikan sengketa berkaitan dengan penegakan kontrak melalui pengadilan, mengukur kualitas proses persidangan, serta menilai kemudahan berbisnis melalui rangkaian proses pada pengadilan. Hal ini menjadi penting masuk dalam indikator EoDB dikarenakan penegakan kontrak yang baik akan memberikan perlindungan dan kepastian hukum yang optimal bagi para investor.

Kesebelas, Penyelesaian Perkara Kepailitan (Resolving Insolvency). Penyelesaian perkara kepailitan adalah 
indikator yang menjadi fokus penelitian penulis. Indikator Penyelesaian Perkara Kepailitan, mengukur waktu penyelesaian perkara, biaya yang dikeluarkan untuk selama perkara, dan hasil persidangan perkara. Semua ini dalam konteks keberhasilan penyelesaian perkara kepailitan.

Gambar C.1. Peringkat EoDB Indonesia 2019

\begin{tabular}{|c|c|c|c|c|c|c|}
\hline Rank & Economy & $\begin{array}{l}E O O B \\
\text { Scove }\end{array}$ & $\begin{array}{l}\text { EOOB } \\
\text { score } \\
\text { change }\end{array}$ & Rank & Economy & $\begin{array}{l}\text { EODB } \\
\text { EOOB score } \\
\text { score change }\end{array}$ \\
\hline 1 & New Lealand & 86.59 & 0.00 & 65 & Colombia & $69.24+0.20$ \\
\hline 2 & Singapore & 85.24 & +0.27 & 66 & Luxembourg & $69.01 \quad 0.00$ \\
\hline 3 & Dentinalk & 84.64 & +0.59 & 67 & Costafica & $68.899 \cdot 0.47$ \\
\hline 4 & Hong Kong SAR, Chind & 84.22 & +0.04 & 68 & Peru & $68.83+0.56$ \\
\hline 5 & Koreze, Rep. & 84.14 & 0.01 & 69 & Vietnam & $68.36+1.59$ \\
\hline 6 & Georgla & 83.28 & +0.48 & 70 & KyrgyzReoublic & $68.33+2.57$ \\
\hline 1 & Noway & 82.95 & +0.25 & 71 & Ukainhe & $68.25+0.94$ \\
\hline 8 & United States & 82.75 & .0 .1 & 12 & Gropon- & ane -012 \\
\hline 9 & United Kingdom & 82.65 & +0.33 & 13 & Indonesia & $67.96+1.427$ \\
\hline 10 & Macedonia, FVR & 81.55 & +0.32 & 74 & Worigulled & $00.14+0.27$ \\
\hline 11 & United Arab Emirateses & 81.28 & +2.37 & 75 & lamaica & $67.47+0.55$ \\
\hline
\end{tabular}

Sumber : World Bank Group. (2019). "Doing Business 2019”, A World Bank Group Flagship Report.

Peringkat kemudahan berbisnis di Indonesia berdasarkan laporan Doing Business 2019, berada pada posisi ke 73 (tujuh puluh tiga). Peringkat EoDB Indonesia tersebut masih jauh dari target yaitu masuk peringkat 40 (empat puluh) besar dunia. Diperlukan suatu terobosan atau pembaruan yang dapat mendukung EoDB yaitu salah satunya dapat dilakukan pada bidang penyelesaian sengketa investasi khususnya terkait penegakan kontrak dan penyelesaian perkara kepailitan.

\section{Gagasan Pembaruan Penyelesaian Sengketa Investasi di Indonesia dalam Mendukung EoDB}

Penanaman modal dalam pelaksanaanya dapat di pengaruhi oleh banyak faktor. Terdapat banyak faktor yang dapat mempengaruhi investor dalam menanamkan modal di suatu negara. Penanaman modal yang memiliki tujuan primer untuk memperoleh keuntungan yang sebesar-besarnya (profit oriented) dan tujuan sekunder untuk memproduksi barang selalu mempertimbangkan berbagai hal sebelum memutuskan berinvestasi. Untuk itu, pemerintah harus berupaya memfasilitasi untuk mencipta-kan suasana yang baik dan kondusif agar investor tertarik menanamkan modalnya.

Salah satu acuan yang digunakan investor dalam mempertimbangakan akan berinvestasi disuatu negara adalah dengan melihat peringkat EoDB negara tersebut. EoDB merupakan peringkat atau indeks kemudahan berbisnis yang dibuat oleh Bank Dunia. Indeks ini merupakan peringkat ekonomi tentang kemudahan berbisnis dalam suatu negara yang diukur berdasarkan penerapan regulasi bisnis kepada perusahaan dan atau pelaku usaha serta pengalaman mereka dalam kegiatan berusaha dan berbisnis. Data Doing Business kerap digunakan untuk menilai kondisi 
perekonomian dan peraturan dalam melakukan penanaman modal asing ke suatu negara atau foreign direct investmen (FDI).

Peringkat kemudahan berbisnis di Indonesia berdasarkan laporan Doing Business 2019, berada pada posisi ke 73 (tujuh puluh tiga). Peringkat EoDB Indonesia tersebut masih jauh dari target yaitu masuk peringkat 40 (empat puluh) besar dunia. Diperlukan suatu terobosan atau pembaruan yang dapat mendukung EoDB yaitu salah satunya dapat dilakukan pada bidang penyelesaian sengketa investasi khususnya terkait penegakan kontrak dan penyelesaian perkara kepailitan.

Dalam hal penegakan kontrak indikator yang diukur adalah terkait biaya dan waktu yang diperlukan dalam menyelesaikan sengketa berkaitan dengan penegakan kontrak melalui pengadilan, mengukur kualitas proses persidangan, serta menilai kemudahan berbisnis melalui rangkaian proses pada pengadilan. Hal ini menjadi penting masuk dalam indikator EoDB dikarenakan penegakan kontrak yang baik akan memberikan perlindungan dan kepastian hukum yang optimal bagi para investor.

Berikut disajikan dalam tabel peringkat kemudahan berbisnis di Indonesia khusus mengenai indikator penegakan kontrak dan penanganan perkara kepailitan:
Tabel C.2. Skor EoDB Penegakan Kontrak dan Penangan Perkara Kepailitan Indonesia (2016 2019)

\begin{tabular}{|l|c|c|c|c|}
\hline \multicolumn{1}{|c|}{ Indikator } & $\begin{array}{c}\text { EoDB } \\
\mathbf{2 0 1 6}\end{array}$ & $\begin{array}{c}\text { EoDB } \\
\mathbf{2 0 1 7}\end{array}$ & $\begin{array}{c}\text { EoDB } \\
\mathbf{2 0 1 8}\end{array}$ & $\begin{array}{c}\text { EoDB } \\
\mathbf{2 0 1 9}\end{array}$ \\
\hline $\begin{array}{l}\text { Penegakan } \\
\text { Kontrak }\end{array}$ & 171 & 166 & 145 & 146 \\
\hline $\begin{array}{l}\text { Penanganan } \\
\text { Perkara }\end{array}$ & 74 & 76 & 38 & 36 \\
Kepailitan & & & & \\
& & & & \\
\hline
\end{tabular}

Sumber : World Bank Group. "Doing Business 2016-2019". A World Bank Group Flagship Report. (data di edit oleh penulis)

Lembaga peradilan dalam kontribusinya terhadap peningkatan indeks kemudahan berbisnis dalam hal ini terkait dengan penegakan kontrak dan penyelesaian perkara kepailitan, dapat dilihat dengan adanya beberapa terobosan diantaranya yaitu menerbitkan Peraturan Mahkamah Agung Nomor 2 Tahun 2015 tentang Tata Cara Gugatan Sederhana atau lebih akrab disebut dengan Small Claim Court, menerbitkan Peraturan Mahkamah Agung Nomor 2 Tahun 2016 tentang Mediasi, menerbitkan Surat Edaran Mahkamah Agung Nomor 2 Tahun 
2016 tentang Peningkatan Efisiensi dan Transparansi Penanganan Perkara Kepailitan dan Penundaan Kewajiban Pembayaran Utang (PKPU) di Pengadilan, menerbitkan Peraturan Mahkamah Agung Nomor 13 Tahun 2016 tentang Tata Cara Penanganan Perkara Tindak Pidana oleh Korporasi, menerbitkan Peraturan Mahkamah Agung Nomor 14 Tahun 2016 tentang Tata Cara Penyelesaian Perkara Ekonomi Syariah, Pembentukan Kelompok Kerja Kemudahan Berusaha melalui Surat Keputusan Ketua Mahkamah Agung Nomor 37/KMA/SK/II/2017, menerbitkan Peraturan Mahkamah Agung Nomor 03 tahun 2018 tentang Administrasi Perkara di Pengadilan Secara Elektronik, mengembangkan Aplikasi e-Court, yang fiturnya tidak hanya sekedar $e$ Filing saja, melainkan juga e-Register, ePayment, e-Notification dan e-Summon.

Terkait dengan penyelesaian perkara kepailitan terdapat beberapa kendala yaitu salah satunya berkenaan dengan beberapa Pasal yang berpotensi digunakan untuk kepentingan tertentu. Kepailitan sendiri diatur dalam UU Kepailitan dan PKPU. UU Kepailitan dan PKPU seolah menjadi mesin pembunuh bagi kelanjutan usaha dari debitor. Pasal 2 ayat (1) UU Kepailitan menegaskan pailit dapat dimohonkan jika memenuhi dua syarat: debitor mempunyai dua kreditor atau lebih dan debitor tidak membayar sedikitnya satu utang yang telah jatuh tempo dan dapat ditagih. Pasal ini, menjadi bukti bahwa UU
Kepailitan bertentangan dengan hakekat dibutuhkan upaya hukum kepailitan yang seharusnya untuk kepentingan seluruh kreditor.

Berdasarkan UU Kepailitan dan PKPU, proses penyelesaian perkara kepailitan hingga kasasi seharusnya di selesaikan dalam waktu 120 hari. Pasal 8 angka 5 menyebutkan putusan pengadilan atas permohonan pernyataan pailit harus diucapkan paling lambat 60 hari setelah tanggal permohonan pernyataan pailit didaftarkan. Sementara dalam Dalam pasal 13 angka 3 menyebutkan bahwa putusan atas permohonan kasasi harus diucapkan paling lambat 60 hari setelah tanggal permohonan kasasi diterima Mahkamah Agung. Dalam pelaksanaanya waktu penyelesaian sengketa kepailitan masih memakan waktu yang sangat lama yaitu rata-rata sekitar delapan bulan.

Masalah lain terkait dengan penyelesaian perkara kepailitan yaitu recovery pasca putusan yang belum memberikan kepastian hukum. Recovery pasca putusan membutuhkan waktu yang tidak sedikit terutama pada perusahaan yang memiliki aset banyak. Namun recovery pasca putusan ini dalam UU Kepailitan dan PKPU tidak diberikan batas waktu yang jelas sehingga dapat menciptakan kepastian hukum.

Diperlukan revisi terkait dengan UU Kepailitan dan PKPU agar lebih memperkuat 
perlindungan bagi investor sehingga dapat mendukung kemudahan berbisnis di Indonesia. Selain itu, diperlukan peraturan pelaksana dari UUPM yang mengatur mengenai penyelesaian sengketa investasi sehingga dapat menciptakan kepastian hukum yang kuat. Peraturan pelaksana ini dapat mengatur mengenai penyelesaian sengketa baik bagi investor dalam negeri maupun dari luar negeri. Penyelesaian sengketa dalam peraturan pelaksana ini diutamakan untuk diselesaikan melalui mekanisme musyawarah mufakat melalui konsultasi dan negosiasi. Mekanisme musyawarah tersebut harus dibatasi dalam jangka waktu tertentu, sehingga ada kepastian bagi investor. Selain itu penyelesaian sengketa dapat dilakukan melaui alternatif penyelesaian sengketa, arbitrase maupun Peradilan.

\section{Penutup}

Pelaksanaan investasi di Indonesia diatur dalam UUPM. Salah satu pembahasan dalam UUPM yaitu terkait dengan penyelesaian sengketa investasi yang diatur tepatnya dalam Pasal 32. Penyelesaian sengketa investasi di bidang penanaman modal antara Pemerintah dengan penanam modal atau para pihak terlebih dahulu harus diselesaikan melalui musyawarah dan mufakat dan apabila tidak tercapai musyawarah mufakat, penyelesaian sengketa tersebut dapat dilakukan melalui arbitrase, APS atau Pengadilan.
Penyelesaian sengketa investasi di Indonesia masih memiliki beberapa permasalahan baik itu dari segi dasar peraturan, proses persidangan dan pelaksanaan putusan. Dalam hal dasar peraturan belum terdapat aturan pelaksana dari UUPM yang fokus membahas penyelesaian sengketa investasi dan dalam UU Kepailitan dan PKPU terdapat beberapa Pasal yang dapat dipergunakan untuk kepentingan tertentu. Pada proses persidangan terdapat masalah waktu yang lama dan dalam hal recovery pasca putusan, UU Kepailitan dan PKPU tidak memberikan batas waktu yang jelas sehingga dapat menciptakan ketidakpastian hukum.

Penyelesaian sengketa investasi dalam mendukung EoDB haruslah cepat, murah, sederhana, dan berkepastian hukum. Guna mewujudkan hal tersebut diperlukan pembaruan hukum penyelesaian sengketa investasi di Indonesia dengan cara membuat peraturan pelaksanaan dari UUPM yang fokus membahas penyelesaian sengketa bisnis agar lebih dapat memberikan kepastian hukum bagi investor dan merevisi beberapa Pasal di UU Kepailitan dan PKPU yang dapat digunakan untuk kepentingan tertentu serta tidak melindungi investor. 


\section{Daftar Pustaka}

\section{Buku dan Jurnal}

Adrian Corcoran dan Robert Gillanders. (2012). "Foreign Direct Investment and The Ease of Doing Business". Review of World Economics 151 (1), 103-126.

Anita Afriana. (2015). "Penerapan Acara Singkat dan Acara Cepat dalam Penyelesaian Sengketa Perdata di Pengadilan: Suatu Tinjauan Politik Hukum Acara Perdata”. Jurnal Hukum Acara Perdata, 1 (1), 31-44.

Frans Hendra Winarta. (2011). Hukum Penyelesaian Sengketa-Arbitrase Nasional Indonesia \& Internasional. Jakarta: Sinar Grafika.

Helmi Kasim. (2018). "Arbitrase sebagai Mekanisme Penyelesaian Sengketa Penanaman Modal". Jurnal RechtsVinding, 7 (1), 79-96.

Huala Adolf. (2006). Hukum Perdagangan Internasional. Jakarta: Raja Grafindo Persada.

Irma Ambarini Darmawan, Isis Ikhwansyah, dan Pupung Faisal. (2018). "CrossBorder Business Competition: Keabsahan dan Hambatan Penerapan Prinsip Ekstrateritorial dalam Penegakan Hukum Persaingan Usaha di Indonesia". Jurnal Bina Mulia Hukum 3 (1), 113-126.

Jamal Ibrahim Haidar. (2012). "The Impact of Business Regulatory Reforms On Economic Growth". Journals of The Japanese and International Economies 26 (3), 285-307.

\footnotetext{
Ratnasari Fajariya Abidin. (2017). "Harmonisasi Peraturan Penanaman Modal Asing dalam Bidang Pertambangan Mineral Dan Batubara Berdasarkan Prinsip Keadilan". Jurnal Az Zarqa, 9 (2), 315-364.
}

Salim HS dan Budi Sutrisno. (2012). Hukum Investasi di Indonesia. (Cetakan Kedua). Jakarta: PT Raja Grafindo Persada.

Suradiyanto. (2015). "Pembangunan Hukum Investasi dalam Peningkatan Penanaman Modal di Indonesia". DIH Jurnal Ilmu Hukum, 11 (21), 25-32.

\section{Peraturan Perundang-undangan}

Undang-undang Dasar Negara Republik Indonesia Tahun 1945.

Undang-undang Nomor 25 Tahun 2007 tentang Penanaman Modal.

Undang-undang Nomor 37 Tahun 2004 tentang Kepailitan dan Penundaan Kewajiban Pembayaran Utang.

Undang-undang Nomor 30 Tahun 1999 Tentang Arbitrase dan Alternatif Penyelesaian Sengketa.

\section{Sumber Lain}

Dias Prasongko. Tempo. https://bisnis. tempo.co/read/1142191/target-eodb40-besar-darmin-nasution-tahun-dep an-harus-radikal/full\&view=ok (diakses 03 Mei 2019).

World Bank Group. (2019). "Doing Business 2019”. A World Bank Group Flagship Report. 